\title{
Distribution of $\mathrm{TNF} \alpha$ and its reactive vascular adhesion molecules in fibrovascular membranes of proliferative diabetic retinopathy
}

\author{
G Astrid Limb, Anthony H Chignell, William Green, Frances LeRoy, Dudley C Dumonde
}

\begin{abstract}
Aims-This study investigated the presence of the cytokine tumour necrosis factor $\alpha(\mathrm{TNF} \alpha)$ and the vascular adhesion glycoproteins ICAM-1, VCAM-1, E-selectin, P-selectin, and PECAM within fibrovascular membranes of eyes with proliferative diabetic retinopathy (PDR).

Methods-The presence of these molecules was determined by immunohistochemical staining using monoclonal antibodies and the APAAP technique.

Results-Staining for TNF $\alpha$ was observed on the retinal vascular endothelium of five of 12 specimens, on infiltrating cells within all membranes, and on the extracellular matrix of nine specimens. This staining was abolished by absorption of the monoclonal antibody with human recombinant TNF $\alpha$. Likewise, ICAM-1 staining was given by infiltrating cells and extracellular matrix of nine membranes and by the endothelium of three of the specimens. VCAM-1, E-selectin, and P-selectin staining was observed on the vascular endothelium of $5 / 12,4 / 12$, and $3 / 12$ epiretinal membranes respectively. PECAM was expressed by the endothelium of $4 / 12$ specimens, by infiltrating cells of $8 / 12$ membranes, and also by the extracellular matrix of two of the specimens.

Conclusion-The widespread distribution of TNF $\alpha$ and the nature of the adhesion molecules expressed by vascular endothelial cells in PDR membranes suggest that local activation of TNF $\alpha$ and enhanced expression of vascular cell adhesion molecules may play an important role in the development of the proliferative phase of diabetic retinopathy.

(Br f Ophthalmol 1996; 80: 168-173)
\end{abstract}

St Thomas's Hospital, London

Department of

Immunology

G A Limb

F LeRoy

D C Dumonde

Department of

Ophthalmology

A H Chignell

W Green

Correspondence to:

Dr G A Limb, Ocular

Rayne Institute, St Thomas'

Hospital, London SE1 7EH.

Accepted for publication

9 November 1995 diabetic retinopathy include damage to, and selective loss of, intramural pericytes from retinal capillaries ${ }^{34}$ with functional damage to the inner blood-retinal barrier. Progressive disease involves activation and proliferation of retinal vascular endothelial cells which in fibrovascular membranes of PDR express the adhesion molecules ICAM-1 and VCAM-1.5
The process of neovascularisation is considered to involve the activation of cell derived angiogenic factors ${ }^{2}$ as well as the appropriate synthesis of extracellular matrix components necessary for anchorage of migrating endothelium. ${ }^{6}$ The cytokine tumour necrosis factor $\alpha$ $(\mathrm{TNF} \alpha)$ is known to alter endothelial cell morphology and behaviour, to play a role in promoting angiogenesis in simplified systems, and to stimulate mesenchymal cells to generate extracellular matrix proteins. ${ }^{78}$ Moreover, in activating endothelium, TNF $\alpha$ enhances ('upregulates') the basal levels of expression of ICAM-1 and PECAM while promoting de novo expression ('inducing') of the adhesion molecules E-selectin, P-selectin, and VCAM..$^{9-11}$ On this basis, it seemed relevant to determine whether TNF $\alpha$ was present in PDR membranes and whether its distribution was related to the expression of a range of vascular adhesion molecules known to be modified by this cytokine.

Accordingly, we set out to investigate PDR membranes for the presence of TNF $\alpha$, and for the expression of ICAM-1, PECAM, Eselectin, P-selectin, and VCAM. By this means we sought to determine whether any deposition of $\mathrm{TNF} \alpha$ in the membranes was associated with supranormal expression of upregulated and induced vascular cell adhesion molecules as judged immunohistochemically by conventional light microscopy.

\section{Materials and methods}

EPIRETINAL MEMBRANES

Fibrovascular epiretinal membranes were obtained from 12 eyes undergoing vitreoretinal surgery for the treatment of PDR complicated by retinal detachment. Immediately after excision membranes were fixed in $4 \%$ paraformaldehyde for 2 hours, immersed in $15 \%$ sucrose in phosphate buffered saline (PBS), and embedded in OCT compound (ICN Biomedical, UK). Specimens were kept in liquid nitrogen until use. Cryostat sections (5 $\mu \mathrm{m}$ thickness) were prepared on poly-Llysine coated slides (Sigma, UK). At least four sections from each of the membranes were processed for immunocytochemistry with each of the antibodies used in the study.
IMMUNOCYTOCHEMICAL (ALKALINE PHOSPHATASE-ANTIALKALINE PHOSPHATASE) STAINING

Epiretinal membrane sections were washed for 5 minutes in TRIS buffered saline $(0.05 \mathrm{M}$ 
Table 1 Distribution of TNF $\alpha$ and vascular cell adhesion molecules in membranes of proliferative diabetic retinopathy

\begin{tabular}{|c|c|c|c|c|c|c|c|c|}
\hline $\begin{array}{l}\text { Specimen } \\
\text { No }\end{array}$ & $\begin{array}{l}\text { Diabetes } \\
\text { type }\end{array}$ & $\begin{array}{l}\text { Duration of } \\
P D R \text { (years) }\end{array}$ & $T N F \alpha$ & $I C A M-1$ & PECAM & $V C A M$ & $\begin{array}{l}E- \\
\text { selectin }\end{array}$ & $\begin{array}{l}P- \\
\text { selectin }\end{array}$ \\
\hline $\begin{array}{r}29 \\
68 \\
80 \\
85 \\
101 \\
118 \\
120 \\
121 \\
126 \\
129 \\
142 \\
163\end{array}$ & $\begin{array}{l}\text { II } \\
\text { I } \\
\text { I } \\
\text { I } \\
\text { II } \\
\text { I } \\
\text { I } \\
\text { I } \\
\text { I } \\
\text { II } \\
\text { II } \\
\text { I }\end{array}$ & $\begin{array}{r}18 \\
15 \\
2 \\
12 \\
6 \\
8 \\
9 \\
13 \\
24 \\
22 \\
5 \\
10\end{array}$ & $\begin{array}{l}++ \\
+ \\
+++ \\
++ \\
++ \\
+++ \\
+++ \\
++ \\
+ \\
++ \\
+ \\
+\end{array}$ & $\begin{array}{l}+ \\
+++ \\
+ \\
++ \\
++ \\
+ \\
++ \\
+ \\
+ \\
+ \\
++ \\
+\end{array}$ & $\begin{array}{l}++ \\
++ \\
++ \\
+++ \\
++ \\
- \\
+++ \\
- \\
- \\
+ \\
++\end{array}$ & $\begin{array}{l}+ \\
- \\
+ \\
- \\
- \\
- \\
- \\
- \\
- \\
+ \\
+ \\
+\end{array}$ & $\begin{array}{l}- \\
+ \\
+ \\
- \\
+ \\
- \\
- \\
- \\
- \\
- \\
+ \\
-\end{array}$ & $\begin{array}{l}+ \\
- \\
- \\
- \\
- \\
++ \\
+ \\
- \\
- \\
- \\
-\end{array}$ \\
\hline
\end{tabular}

TNF $\alpha=$ tumour necrosis factor $\alpha ;$ PDR = proliferative diabetic retinopathy; ICAM-1 = intercellular adhesion molecule-1; VCAM=vascular cell adhesion molecule.

Staining was graded as absent $(-)$, mild $(+)$ when $1-5$ positive cells were present per $\mathrm{mm}^{2}$ of ctaining tssue, and/or there was a mild staining of defined compartments of retinal membranes (for example, endothelium or extracellular matrix); moderate $(++)$ when $6-12$ positive cells were present per $\mathrm{mm}^{2}$ of tissue, and/or there was a moderate staining of defined areas of membranes; and marked $(+++)$ when both cell associated and extracellular matrix staining was observed throughout the membranes. graded as mild $(+)$ when there were either $1-5$ positive cells per $\mathrm{mm}^{2}$ of tissue, or a mild staining of defined compartments of retinal membranes (for example, endothelium or vessel walls); moderate $(++)$ when $6-12$ positive cells were present per $\mathrm{mm}^{2}$ of tissue and/or there was a moderate staining of defined areas of membranes; and marked $(+++)$ when a widespread staining of both cells and extracellular matrix was observed throughout the membranes.

To determine the specificity of staining for TNF $\alpha$ by retinal specimens, the anti-TNF $\alpha$ antibody was absorbed with human recombinant TNF $\alpha$ (R\&D Systems, Abingdon, UK) in a solid phase using flat bottomed enzyme linked immunosorbent assay (ELISA) plates (Nunc). Briefly, plates were coated with $\mathrm{TNF} \alpha$ by overnight incubation at $4^{\circ} \mathrm{C}$ with $100 \mu \mathrm{l}$ per well of the recombinant proteins $(10 \mu \mathrm{g} / \mathrm{ml}$ in

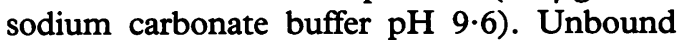
cytokine was removed by washing the plates four times with PBS. Aliquots of $100 \mu \mathrm{l}$ from a working dilution of the anti-TNF $\alpha$ antibody were added to the wells and the plates incubated for 1 hour at room temperature with frequent shaking. Partially absorbed antibody was then transferred onto new $\mathrm{TNF} \alpha$ coated wells, and the process repeated six times to ensure that at least $95 \%$ of the antibody specificity has been removed. This was confirmed by determination of the proportion of antibody bound to the plates using an ELISA method as previously described. ${ }^{12}$ (Serotec, UK), or mAb AC1.2 detecting Pselectin (Becton Dickinson, UK). Negative controls included omission of $\mathrm{mAb}$ and its replacement by TBS or mouse IgG (The Binding Site Ltd, UK). Sections were then rinsed briefly with TBS, washed in the same buffer for 2 minutes, and incubated for 30 minutes at room temperature with $30 \mu \mathrm{l}$ rabbit polyclonal anti-mouse IgG antibody reagents (Dakopatts, Denmark) diluted 1:10 in TBS. Slides were rinsed, washed as above, and sections were further incubated for 30 minutes with soluble complexes of alkaline phosphatase and monoclonal mouse anti-alkaline phosphatase (APAAP, Dakopatts) at a 1:20 dilution in TBS. After a 2 minute wash the rabbit anti-mouse antibody and APAAP reagent steps were repeated for 10 minutes each to enhance the intensity of staining. Sections were then incubated for 30 minutes at room temperature with $50 \mu$ l alkaline phosphatase substrate prepared by dissolving $1.2 \times 10^{-3} \mathrm{M}$ AS-MX phosphate (Sigma, UK) in $0.25 \mathrm{M} \mathrm{N}, N-$ dimethylformamide (Sigma, UK) which was then diluted $1: 50$ with $0 \cdot 1 \mathrm{M}$ TRIS- $\mathrm{HCl}$ buffer pH 8.2 containing $1 \times 10^{-3} \mathrm{M}$ levamisole (Sigma, USA). This solution was stored at $-20^{\circ} \mathrm{C}$ in $5 \mathrm{ml}$ aliquots, and $5 \mathrm{mg}$ of fast red TR salt (Sigma, UK) was added to each aliquot at the time of use. Sections were finally washed briefly with TBS and deionised water for 2 minutes each, and counter stained with Mayer's haematoxylin (Sigma, UK) for 5 minutes. After rinsing under tap water and air drying, slides were mounted with Glycergel (Dakopatts). Positively reacting cells or tissue were identified by cell surface or extracellular distribution of red staining. Positivity was

\section{Results}

Table 1 presents the prevalence of staining adhesion molecules in the PDR membranes investigated. Table 2 summarises the clinical history, examination, and follow up of the patients undergoing vitreoretinal surgery for the treatment of PDR.

\section{DISTRIBUTION OF TNF $\alpha$ WITHIN}

FIBROVASCULAR MEMBRANES OF PDR

Staining for $\mathrm{TNF} \alpha$ was observed on various components of all 12 membranes. Figure 1 shows that cytokine staining was detected on vascular endothelium (in five membranes: Fig 1A), on cells infiltrating all membranes (Fig 1B), and on extracellular matrix (of nine specimens: Fig 1C). Absorption of the antiTNF $\alpha$ antibody reagent with human recombinant TNF $\alpha$ removed all staining (Fig 1D).

PRESENCE OF VASCULAR ENDOTHELIAL CELL ADHESION MOLECULES WITHIN PDR MEMBRANES

Various patterns of staining with the antiICAM-1 reagent were observed in nine of the 12 epiretinal membranes studied. Staining of vascular endothelium was observed in four of the membranes (Fig 2A), while staining of extracellular matrix was seen in five specimens (Fig 2B). All nine specimens contained ICAM-1 positive cells distributed throughout for TNF $\alpha$ and its reactive endothelial cell 
Table 2 Clinical history of patients undergoing vitreoretinal surgery for the treatment of PDR

\begin{tabular}{|c|c|c|c|c|c|c|c|c|c|}
\hline \multirow{2}{*}{$\begin{array}{l}\text { Laboratory } \\
\text { No }\end{array}$} & \multirow[b]{2}{*}{ Age } & \multirow[b]{2}{*}{ Sex } & \multirow{2}{*}{$\begin{array}{l}\text { Laser } \\
\text { treatment }\end{array}$} & \multirow{2}{*}{$\begin{array}{l}\text { Previous } \\
\text { vitrectomy }\end{array}$} & \multirow{2}{*}{$\begin{array}{l}\text { Previous } \\
\text { vitreous } \\
\text { haemorrhage }\end{array}$} & \multirow{2}{*}{$\begin{array}{l}\text { Status of } P D R \\
\text { at surgery }\end{array}$} & \multirow{2}{*}{$\begin{array}{l}\text { Further } \\
\text { operations }\end{array}$} & \multicolumn{2}{|c|}{ Visual acuity } \\
\hline & & & & & & & & Before & After \\
\hline $\begin{array}{r}29 \\
68 \\
80 \\
85 \\
101 \\
118 \\
120 \\
121 \\
126 \\
129 \\
142 \\
163\end{array}$ & $\begin{array}{l}69 \\
56 \\
44 \\
25 \\
50 \\
30 \\
28 \\
54 \\
46 \\
52 \\
67 \\
54\end{array}$ & $\begin{array}{l}M \\
M \\
M \\
F \\
M \\
F \\
M \\
F \\
M \\
M \\
M \\
M\end{array}$ & $\begin{array}{l}\text { PRP } \\
\text { PRP } \\
\text { PRP } \\
\text { PRP } \\
\text { PRP } \\
\text { PRP } \\
\text { PRP } \\
\text { PRP } \\
\text { PRP } \\
\text { PRP } \\
\text { Focal } \\
\text { PRP }\end{array}$ & $\begin{array}{l}\text { Yes } \\
\text { No } \\
\text { No } \\
\text { No } \\
\text { No } \\
\text { No } \\
\text { No } \\
\text { No } \\
\text { No } \\
\text { No } \\
\text { No } \\
\text { No }\end{array}$ & $\begin{array}{l}\text { Yes } \\
\text { Yes } \\
\text { Yes } \\
\text { No } \\
\text { Yes } \\
\text { No } \\
\text { Yes } \\
\text { Yes } \\
\text { No } \\
\text { Yes } \\
\text { No } \\
\text { No }\end{array}$ & $\begin{array}{l}\text { Ischaemic TRD } \\
\text { Active PDR } \\
\text { Active PDR } \\
\text { Active PDR/RD } \\
\text { Active PDR/TRD } \\
\text { Active PDR } \\
\text { Active PDRTRD } \\
\text { TRD } \\
\text { Active PDR/TRD } \\
\text { Ischaemic TRD } \\
\text { Extensive PDR/TRD } \\
\text { Active PDR }\end{array}$ & $\begin{array}{l}1(\mathrm{v}) \\
0 \\
0 \\
0 \\
0 \\
1(\mathrm{c}) \\
0 \\
0 \\
2(\mathrm{v}) \\
0 \\
1(\mathrm{c}) \\
0\end{array}$ & $\begin{array}{l}6 / 24 \\
\text { PL } \\
\text { CF } \\
6 / 10 \\
\text { PL } \\
\text { HM } \\
\text { PL } \\
\text { HM } \\
6 / 24 \\
\text { CF } \\
\text { HM } \\
6 / 60\end{array}$ & $\begin{array}{l}6 / 18 \\
\text { CF } \\
6 / 24 \\
\text { HM } \\
\text { CF } \\
\text { CF } \\
\text { HM } \\
\text { HM } \\
6 / 18 \\
6 / 60 \\
\text { HM } \\
\text { HM }\end{array}$ \\
\hline
\end{tabular}

$\mathrm{PDR}=$ proliferative diabetic retinopathy; $\mathrm{PRP}=$ panretinal photocoagulation; $\mathrm{TRD}=$ traction retinal detachment; $(\mathrm{v})=$ vitreoretinal surgery; $(c)=$ cataract surgery; $P L=$ perception of light; $C F=$ count fingers; $H M=$ hand movements.

the membranes. The anti-PECAM antibody stained eight of the 12 epiretinal membranes and, as with the distribution of ICAM-1, staining for PECAM was observed on vascular endothelium (four membranes), extracellular matrix (two membranes), and on infiltrating cells throughout all eight membranes (Fig 2C). Unlike the distribution of ICAM-1 and PECAM, staining for VCAM-1, E-selectin, and P-selectin was given by vascular endothelium only; this was observed in five, four, and three membrane specimens respectively (Figs 3A-C). Multiple staining for reactive adhesion molecules was present in some of the specimens: of the nine membranes positive for ICAM-1, eight stained for PECAM, two stained for the inducible adhesion molecules VCAM and E-selectin, one stained for VCAM only, another two stained for E-selectin, one other was positive for VCAM and P-selectin, while another two stained for P-selectin only.
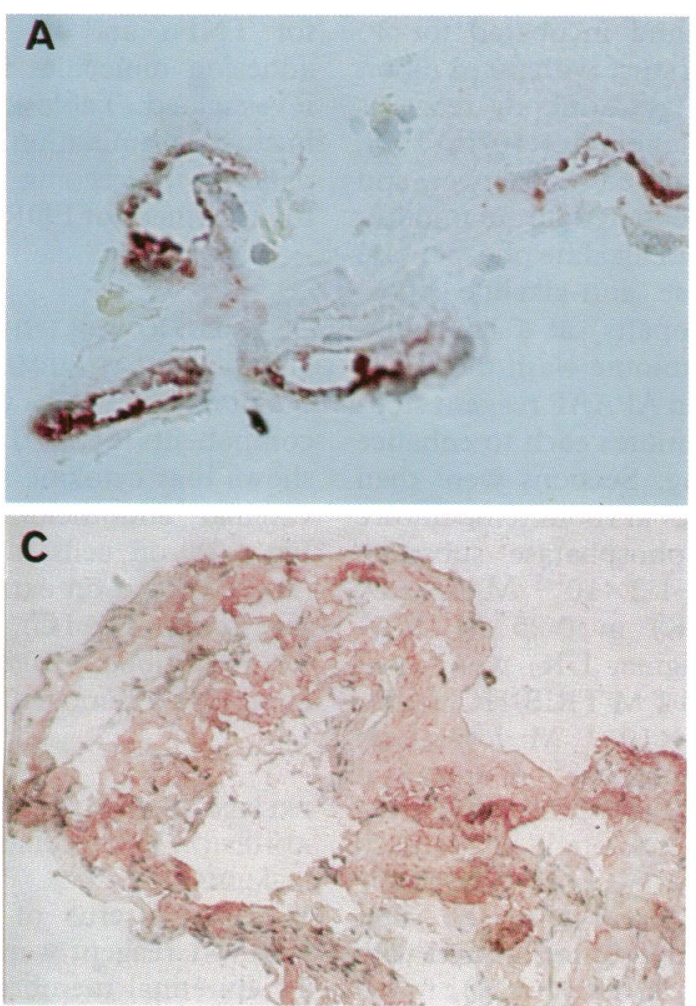

Figure 1 Immunohistochemical staining of fibrovascular epiretinal membranes of proliferative diabetic retinopathy with anti-TNF $\alpha$ antibody. (A) Positive staining for TNF $\alpha$ by endothelium lining the retinal vessels (specimen 121)

Magnification $\times 180$. (B) Staining for TNF $\alpha$ by both infiltrating cells (arrows) and extracellular matrix (specimen 85). Magnification $\times 180$. (C) Widespread staining of the extracellular matrix for TNF $\alpha$ (specimen 120). Magnification $\times 95$. (D) Adjacent section of the same membrane stained with anti-TNF $\alpha$ antibody absorbed with human recombinant TNF . Sections counterstained with Mayer's haematoxylin. Magnification $\times 95$.

None of the 12 membranes stained for all adhesion molecules together (Table 1).

Although antibodies to both $\mathrm{TNF} \alpha$ and ICAM-1 stained the extracellular matrix of three specimens $(68,85$, and 101) and antibodies to TNF $\alpha$, ICAM, and PECAM stained the extracellular matrix of one specimen (120), the same membrane regions did not appear to stain for the two molecules. We considered that identification of colocalisation of TNF $\alpha$ with one or more vascular adhesion molecules would be more appropriately investigated by multiple staining and confocal microscopy.

\section{DISEASE ASSOCIATIONS OF TNF $\alpha$ AND}

ADHESION MOLECULE STAINING deposition showed no evident relation to the type of diabetes, sex, age, known duration of PDR in years, previous laser treatment,
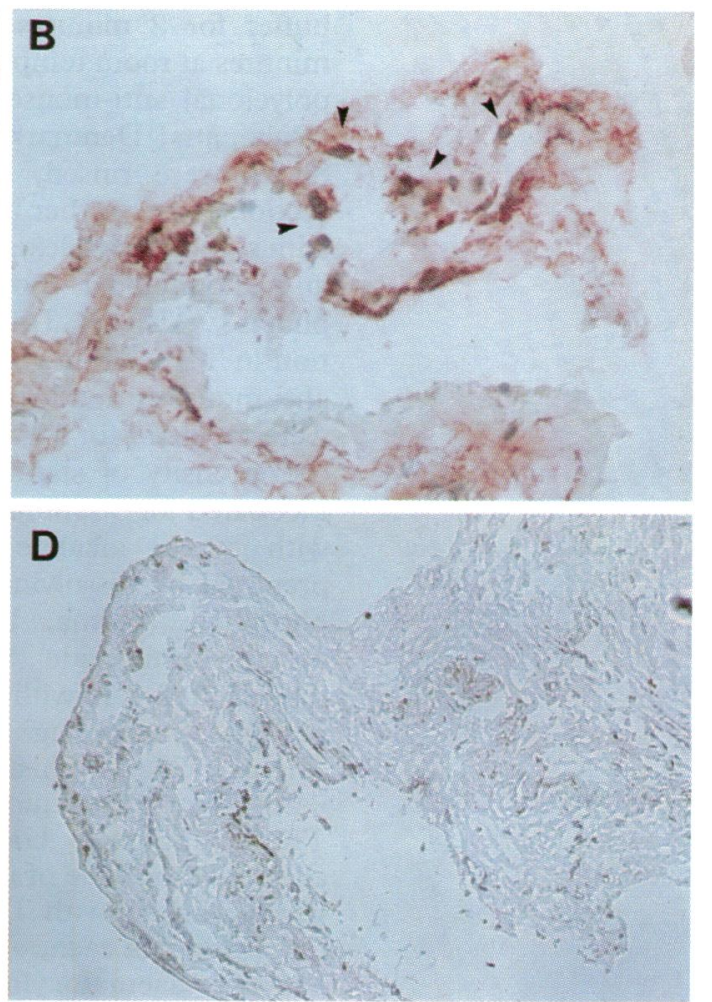

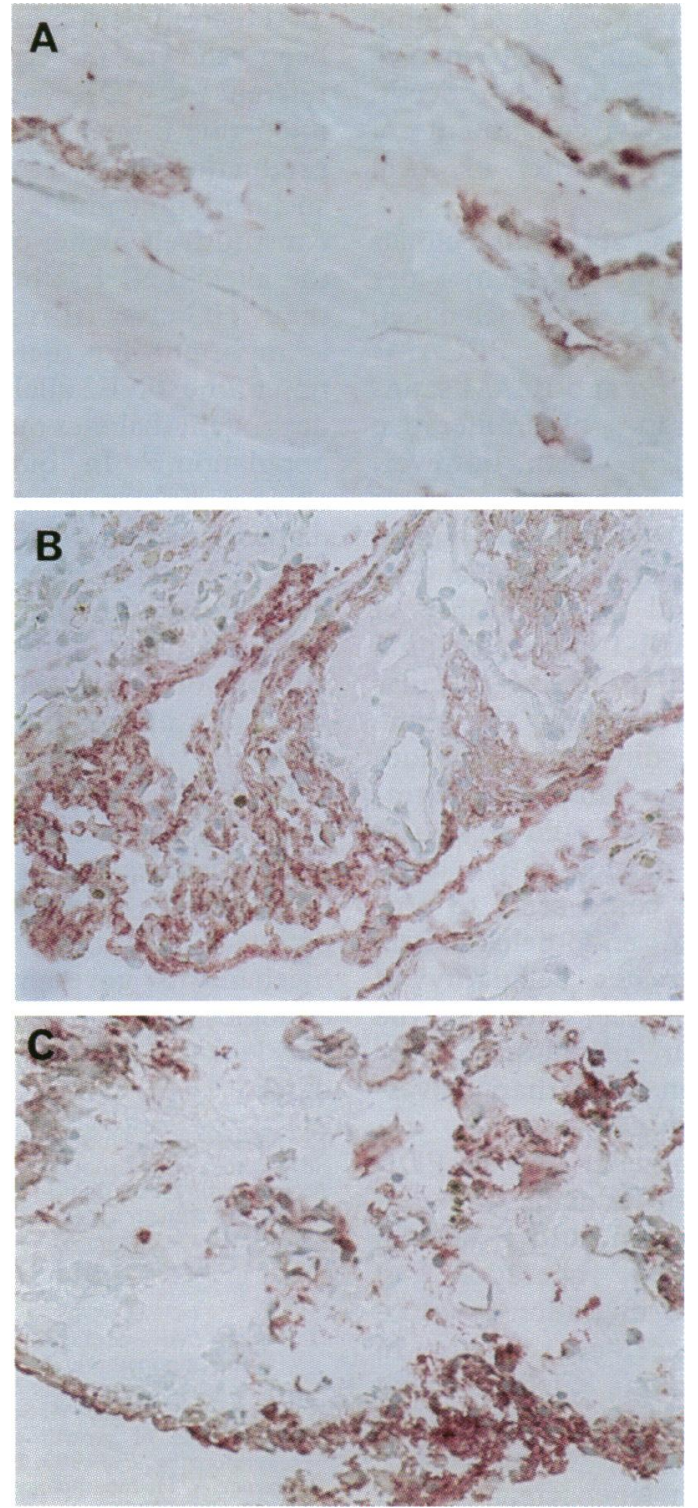

Figure 2 Photomicrographs showing immunohistochemical staining for ICAM-1 and PECAM within epiretinal membranes of PDR. (A) Positive staining for ICAM-1 by retinal vascular endothelium (specimen 80 ). Magnification $\times 180$. (B) Widespread distribution of ICAM-1 within cells and extracellular matrix (specimen 120). Magnification

$\times 180$. (C) Staining of infiltrating cells and vascular endothelium with anti-PECAM antibodies (specimen 85). Sections counterstained with Mayer's haematoxylin. Magnification $\times 95$.

previous vitreous haemorrhage, status of retinopathy at the time of surgery, or outcome of the surgery (Tables 1 and 2). Likewise, there was no selective relation between the distribution of any one or more of the vascular adhesion molecules within fibrovascular retinal membranes and the type of diabetes, duration of PDR, or any other clinical features (Tables 1 and 2).

\section{Discussion}

The present investigation shows that the cytokine $T N F \alpha$ is widely distributed within fibrovascular membranes of PDR, and that multiple staining for both upregulated (ICAM1, PECAM) and induced (VCAM-1, E-selectin, $P$-selectin) vascular adhesion molecules is found frequently in PDR membranes.
TNF $\alpha$ showed various patterns of deposition within all 12 PDR membranes. This cytokine was detected not only on infiltrating cells and on vascular endothelium, but also within the extracellular matrix of various specimens. Although abrogation of staining by absorption of the monoclonal anti-TNF $\alpha$ antibody with human recombinant $T N F \alpha$ suggested that the immunoreactivity was most probably because of the presence of $T N F \alpha$, fortuitous cross reactivity of the antibody with other extracellular or cell associated molecules could not be entirely excluded. That anti$\mathrm{TNF} \alpha$ antibody stained the extracellular matrix of PDR membranes is compatible with our previous findings that $\mathrm{TNF} \alpha$ binds readily to fibronectin and collagen type IV without losing its biological activity ${ }^{13}$ and that PDR vitreous rarely contains bioactive $T N F \alpha .{ }^{14}$ Evidence implicating $\mathrm{TNF} \alpha$ in the pathogenesis of PDR would be strengthened by showing TNF-like bioactivity associated with explanted membranes. On this basis, an
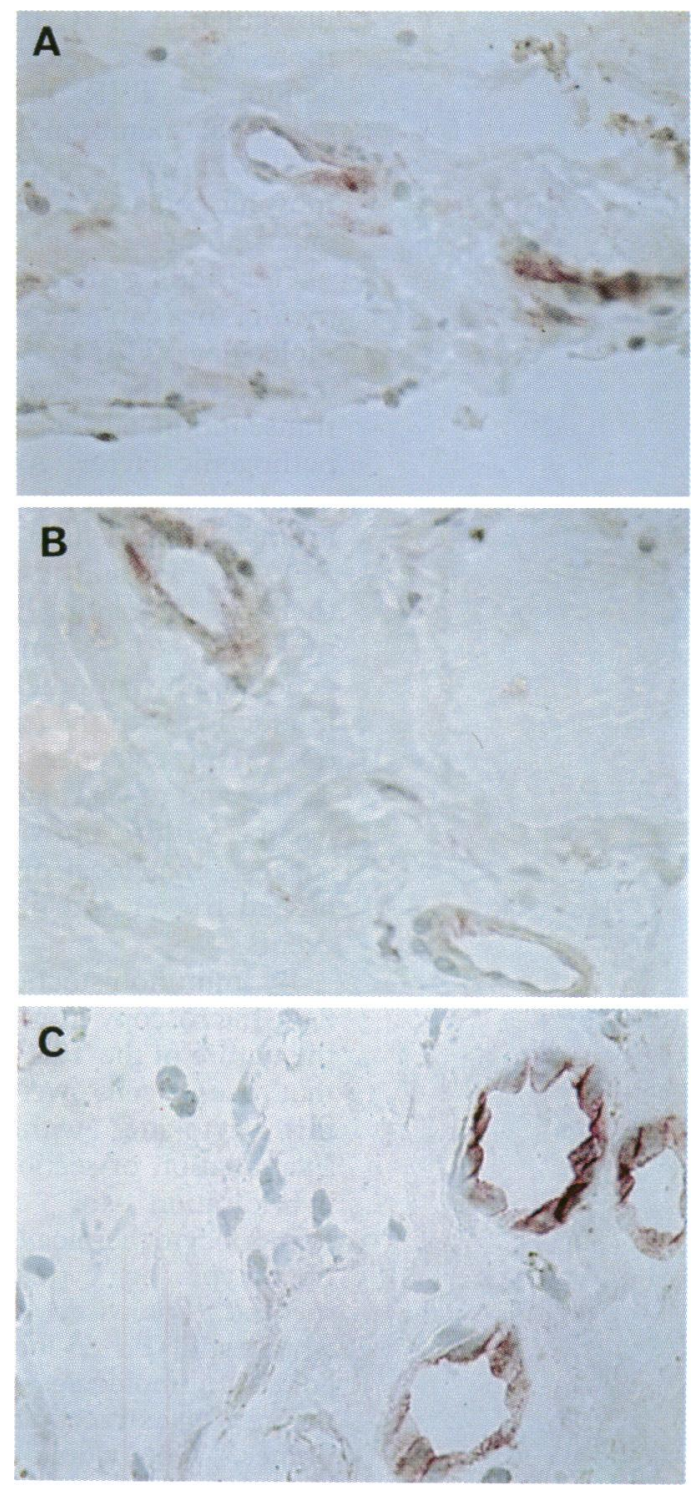

Figure 3 Immunohistochemical staining of epiretinal membranes of $P D R$ for cytokine inducible vascular cell adhesion molecules. (A) Staining for VCAM-1 (specimen 80). (B) Staining for E-selectin (specimen 142). (C) Staining for P-selectin (specimen 118). Sections counterstained with Mayer's haematoxylin. Magnification countersta
$\times 180$. 
important pathogenetic pathway maintaining angiogenesis in PDR could well involve adsorption of bioactive cytokine to fibronectin and collagen type IV, known constituents of PDR membranes, ${ }^{615}$ shortly after its local generation.

Staining of both cells and extracellular matrix (Table 1; Figs 1-3) of PDR membranes for TNF $\alpha$ and upregulated endothelial cell adhesion molecules (ICAM-1, PECAM) recalls our findings of TNF $\alpha$ and ICAM staining in epiretinal membranes of proliferative vitreoretinopathy (PVR) ${ }^{16} 17$ which, however, are characteristically avascular. The apparent similarity would seem to lie in the known ability of non-endothelial and endothelial cells to generate ICAM-1 and in the ability of TNF $\alpha$ to upregulate ICAM-1 expression on a variety of cell types. ${ }^{18}$ In PDR the vascular endothelial cell would be viewed as the prime target of TNF activity, leading to overproduction of basement membrane and other extracellular matrix proteins. This could serve as a scaffold for continued angiogenesis, while upregulation of ICAM-1 could serve to promote selective leucocyte endothelial interaction. In PVR the greater cellularity of epiretinal membranes suggests a role of the TNF $\alpha / \mathrm{ICAM}-1$ axis in promoting pleomorphic cell accumulation rather than neovascularisation.

Our finding that endothelial cells of PDR membranes can express the inducible adhesion molecules VCAM, E-selectin, and P-selectin indicates the continued operation of transendothelial leucocyte migration as a copathogenic factor. An accepted sequence of events views contact of rolling leucocytes with intimal endothelium as being initiated by PECAM, E- and P-selectins (on the endothelium) interacting with leucocyte adhesion molecules. ${ }^{9-11}$ Stronger adhesion is then generated by endothelial ICAM-1 and VCAM interacting with the leucocyte integrins $\beta 2$ and $\alpha 4 .^{19}$ Our evidence that expression of both $\mathrm{TNF} \alpha$ and of vascular cell adhesion molecules occurs within individual PDR membranes suggests that local production of TNF $\alpha$ may indeed trigger and maintain this sequence of events.

By immunohistochemistry and conventional light microscopy it was not possible to identify the nature of the TNF reactive cells, or to infer that these cells were the main source of this cytokine within PDR membranes. Examination of sections by combining in situ hybridisation for cytokine mRNA with immunocytochemical identification of cell phenotype or cytokine protein is thereby merited. Likewise, we could not determine whether TNF $\alpha$ co-localised with one or more adhesion molecules within vascular endothelium or extracellular matrix of PDR membranes. This would be more appropriately investigated by multiple staining of individual membranes and confocal microscopy.

The question naturally arises of whether patients with diabetic retinopathy might be high producers of TNF $\alpha$; and formal experiment is awaited. Supranormal production of
TNF $\alpha$ from peripheral blood cells in vitro has been shown in type I diabetes without reference to $P^{20}{ }^{20}$ as well as by patients with idiopathic retinal vasculitis in relapse. ${ }^{21}$ TNF production is governed by promoter alleles such that individuals with the allele TNF2 are constitutively higher producers than those with the allele TNF $1,{ }^{22}$ both being represented in the MHC class III region. ${ }^{23}$ In this context, it is important that there is a higher representation of the TNF2 allele in patients with insulin dependent diabetes mellitus than in the normal population. ${ }^{23}$ In our study there was no obvious difference between type I and type II diabetes mellitus in the expression of TNF $\alpha$ and its reactive adhesion molecules on PDR membranes, whether of the upregulated or inducible class. Studies involving a larger number of specimens may give a more clear indication of any differences between the two groups.

In conclusion, we suggest that local deposition of TNF $\alpha$ and of its reactive vascular adhesion molecules may be an important step in the pathogenesis of proliferative diabetic retinopathy. Clarification of local and systemic mechanisms governing the production and biological activity of TNF $\alpha$ in these patients may lead to a greater understanding of the condition.

The authors thank Dr Sue Stephens (Celltech Ltd, UK) for the gift of anti-TNF $\alpha$ antibodies, Dr Barry Hartley, FRCPath, for discussion of the immuno-histochemical staining results, and Mrs Dora Paterson for typing the manuscript.

Research was supported by The Thomas Pocklington Trust and The Guide Dogs for the Blind Association.

1 Boulton ME, McLeod D, Garner A. Vasoproliferative vitreoretinopathies: clinical, morphogenetic and modulavitreoretinopathies: clinical, morphogenetic
tory aspects. Eye 1988; 2 (suppl 1): 124-39.

2 Forrester JV, Shafiee A, Schröder S, Knott R, McIntosh L. The role of growth factors in proliferative diabetic retinopathy. Eye 1993; 7: 276-87.

3 Garner A. Histopathology of diabetic retinopathy in man. Eye 1993; 7: 250-3.

4 Hamilton CW, Chandler D, Klintworth GK, Machemer RA. A transmission and scanning electron microscopic study of surgically excised preretinal membrane proliferations in diabetes mellitus. Am $\mathcal{f}$ Ophthalmol 1982; 94: 473-88.

5 Tang S, Le-Ruppert KC, Gabel V-P. Expression of intercellular adhesion molecule-1 (ICAM-1) and vascular cell adhesion molecule-1 (VCAM-1) on proliferating vascular endothelial cells in diabetic epiretinal membranes. $\mathrm{Br} \tilde{J}$ Ophthalmol 1994; 78: 370-6.

6 Hiscott P, Waller HA, Grierson I, Butler MG, Scott DL. The extracellular matrix of reparative tissue in the vitreous:fibronectin production in proliferative diabetic retinopathy membranes. Eye 1993; 7: 288-92.

7 Stolpen AH, Guinan EC, Fiers W, Pober JS. Recombinant tumor necrosis factors and immune interferon act singly and in combination to reorganize human vascular and in combination to reorganize human vascular 16-24.

8 Liebovich SJ, Polverini PJ, Shephard HM, Wiseman DM, Shively V, Nuseir N. Macrophage induced angiogenesis is mediated by tumour necrosis factor alpha. Nature 1987 329: 630-2.

9 Wellicome SM, Thornhill MH, Pitzalis C, Thomas DS, Lanchbury JS, Panayi GS, et al. A monoclonal antibody that detects a novel antigen on endothelial cells that is induced by tumor necrosis factor, IL-1 or lipopolysaccha-

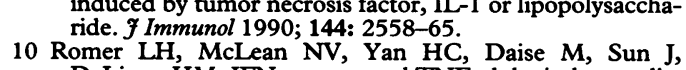
DeLisser HM. IFN-gamma and TNF-alpha induce redistribution of PECAM-1 (CD31) on human endothelial tribution of PECAM-1 (CD31) on
cells. F Immunol 1995; 154: 6582-92.

11 Luscinskas FW, Ding H, Lichtman AH. P-selectin and vascular cell adhesion molecule-1 mediate rolling and arrest, respectively, of $\mathrm{CD4}^{+} \mathrm{T}$ lymphocytes on tumor necrosis factor $\alpha$-activated vascular endothelium under flow. $\mathcal{F}$ Exp Med 1995; 181: 1179-86.

12 Limb GA, Meager A, Woolley J, Wadhwa M, Biggerstaff J, Brown KA, et al. Release of cytokines during generation of lymphokine-activated killer (LAK) cells by IL-2. Immunology 1989; 68: 514-9.

13 Sethna F, Limb GA, Ellis B, Saundry R, Dumonde DC. Cytokine binding to extra-cellular matrix proteins. Immunology 1994; 83 (suppl): 81. 
14 Franks WA, Limb GA, Stanford MR, Ogilvie J, Wolstencroft RA, Chignell AH, et al. Cytokines in human intraocular inflammation. Curr Eye Res 1992; 11 (suppl): 187-91.

15 Sheiffarth OF, Kampik A, Guenther H, vd Mark K Proteins of the extra-cellular matrix in vitreoretinal membranes. Graefes Arch Clin Exp Ophthalmol 1988; 226: 357-61.

16 Limb GA, Franks WA, Munasinghe KR, Chignell AH, Dumonde DC. Proliferative vitreoretinopathy: an examination of the involvement of lymphocytes, adhesion molecules and HLA-DR antigens. Graefes Arch Clin Exp
Ophthalmol 1993; 231: 331-6.

17 Limb GA, Alam E, Earley O, Chignell AH, Dumonde DC. Distribution of cytokine proteins within epiretinal membranes in proliferative vitreoretinopathy. Curr Eye Res 1994; 13: 791-8.

18 Camussi G, Albano E, Tetta C, Bussolino F. The molecular action of tumor necrosis factor- $\alpha$. Eur $\mathcal{F}$ Biochem 1991; 202: 3-14.
19 Cronstein BN, Weissmann G. The adhesion molecules of inflammation. Arthr Rheum 1993; 36: 147-57.

20 Pociot F, Briant L, Jongeneel CV, Molvig J, Worsaae H, Abbal M, et al. Association of tumor necrosis factor (TNF) and class II major histocompatibility complex alleles with the secretion of TNF $\alpha$ and TNF $\beta$ by human mononuclear cells: a possible link to insulin-dependent diabetes mellitus. Eur f Immunol 1993; 23: 224-31.

21 Ellis BA, Patel SY, Stanford MR, Zaman AG, Graham EM, Dumonde DC, et al. Tumor necrosis factor production by lipopolysaccharide-stimulated peripheral blood mononuclear cells from patients with retinal vasculitis. Reg Immunol 1994; 6: 27-30.

22 Wilson AG, Symonds JA, McDowell TL, di Giovine FS, Duff $G W$. Effects of a tumour necrosis factor (TNF $\alpha$ ) promoter base transition on transcriptional level. $\mathrm{Br} \mathcal{F}$ Rheumatol 1994; 33 (suppl 1): 89.

23 Cox A, Gonzales AM, Wilson AG, Wilson RM, Ward JD, Arlett CM, et al. Comparative analysis of the genetic associations of HIA-DR3 and tumour necrosis factor alpha with human IDDM. Diabetologia 1994; 37: 500-3. 